\title{
Assessing the Influence of Religiosity and Spirituality Practices on Human Resources Performances at Workplaces, Ghana
}

\author{
Charles Aidoo Tawiah ${ }^{1 *} \quad$ Augustina Kyeraa ${ }^{2} \quad$ Patrick Twumasi Frimpong ${ }^{3} \quad$ Hans Kwaku Duah $^{4}$ \\ 1.Department of Social Sciences and Humanities, University of Cape Coast, Berekum College of Education, \\ Berekum, Ghana \\ 2.Department of Administration, University of Cape Coast, Berekum College of Education, Berekum, Ghana \\ 3.Accounts Department, Sunyani Technical University, Sunyani, Ghana \\ 4.Department of Social Sciences and Humanities Berekum College of Education, Berekum, Ghana
}

\begin{abstract}
The way workers react to instructions, devote time for productive activities and leisure, dress codes, sharing of resources and responses to organisational calls, attitudes and behaviours are determined by their religion and spiritual beliefs. These practices at the working environment will either impede or enhance productivity. Religiosity and spirituality either positively or negatively affects employee's performance in an organisational setting. Questionnaire, interview, observation and Focus Group Discussions were the main data collection techniques used in this study. Simple random sampling and simple proportion formula were used in selecting sample size for each organisation studied. The study revealed that there is highly significant association between religiosity/spirituality and employee's performance which positively influenced productivity at workplaces. Benefits such as commitment, honesty and creativity enhanced productivity. It was empharcized that majority of employees who are highly religious and spiritual communicate with their Divine every day before they commenced their official functions at work places. Nevertheless, the study discovered that too much religiosity and spirituality reduced productivity because working hours will be used for practicing religion. The study therefore recommend that management must designate special areas for religious activities like prayers and meditations for the employees to dialogue with their maker and organisation's policies must be reviewed to shape religious practices and spiritual activities at work places to reduce its influence on productivity in Ghana.
\end{abstract}

Keywords: Religiosity, Spirituality, Human Resources performances

DOI: $10.7176 / \mathrm{EJBM} / 13-10-09$

Publication date:May $31^{\text {st }} 2021$

\section{Introduction}

The important role that religiosity and spirituality play in our live is not doubt (Fox et al, 2018). In this regard, Tylor (1976) defined religion as the belief in spiritual beings. In his estimation, Tylor postulated that where there exists the belief in spiritual beings, such a belief can be referred to as religion. Abu Bakar et al (2018) explained religion as human beings' relation to that which they consider as holy, sacred, spiritual or divine. In the same way religion is defined as a personal set or institutionalized system of religious beliefs, attitudes and practices; a cause, principle, or system of beliefs held to or have faith according to Cullen (2016). On the other hand, various definitions have been assigned to spirituality by different scholars. According to McCormick (1994), spirituality can be defined as one's inner experience which can be expressed through his conduct. Thus to say that an individual's personal expression of conduct or behaviour in the public life demonstrates spirituality.

Besides, the practice of religiosity and spirituality have established actual peace in Ghana and brought happiness to individual people as indicated by Abu Bakar et al, (2018). Also, the kindness, sympathy, love and generosity that people exhibit stems from the guiding principles derived from religious and spiritual practices and that individuals perform good acts through appeal to their Divine and not through the use of coercive force. In Ghana, religion is the source that gives guidelines to progress for man both from the material and the spiritual perspectives. They are also of the view that no individual can discuss the issues of morality and virtue without reference to religion since morality and virtue emanates from one's good and clear conscience. Then, what links humankind to God is religion and at the same time provides for an individual's good and clear conscience (Gordon, 2018).

Furthermore, it is stipulated that, practical activities individuals exhibit at workplaces to demonstrate their religiosity include recitation of prayers every day (Milliman, 2018). Thus, it is a common sight to find workers or managers praying in their offices. This is also true to see a whole group of workers beginning their daily activities with an organized prayer service. Milliman, (2018) continued to show that, some employees can put on religious regalia or artifacts like the crucifix, rosary, and 'tasbar' to their places of work. Milliman in 2018 wrote that religious headscarves are normally put on by women especially the types designed with religious logos and ' $h i j a b$ ' (headscarf) by Muslim women and the cap by the men. Most workers hang printed religious pennants in their cars, paste posters and calendars in their offices to demonstrate their religiosity and spirituality. It is also a common sight as stated by Milliman, (2018) that on the tables or office desks can be found religious scriptures and tracts 
which are read by owners or possessors. He goes on to say that meditations by some workers are also rampant. Workers can be asked to watch the sun from their conference rooms together. That is to say that, organisations can organize religious activities for the whole workers to take part. For instance, in November $20^{\text {th }}$, 2018, a giant pharmaceutical company in Ghana called Tobinco Pharmaceutical Company Ltd., organized all-night vigil for all workers to pray for the success of the company when some of their imported drugs or products were seized by the Foods and Drugs Authority (FDA). The case was threatening the survival of the company. They prayed for God's intervention because the company attributed their problems to the work of some unseen hands or forces or they attributed their woes to the work of evil spirits (Vasconcelos, 2018). It was also observed that the Ghana Police Service, politicians, soldiers and other state institutions organised the end of year prayer and thanksgiving service to thank God for a successful year and they attributed their success to the work of the Supreme Being (God). They are of the view that religiosity and spirituality exhibited by workers at the workplace comprises how one thinks about himself, his or her work, and the organisation which provides work for him or her to make a living.

It is on this basis that made Fox et al (2018) stated that during festive occasions like the Muslim end of Ramadan period -'Idr ul Fitr' and 'Idr ul Adha' celebrations and Christmas and Easter seasons being celebrated by Christians, all government and majority of private companies closed work for at least four days to enable the employees to participate actively in the celebrations. Mahmood (2018) stated that any attitude exhibited by employees which resembles that of a servant's behaviour towards an individual's occupation and management is a sign of spirituality.

He again pointed out that as one demonstrates respect, honesty and a high sense of integrity, it shows spirituality at work (Mahmood et al, 2018). Exhibition of spirituality at workplaces and politics has become the order of the day and the question is, how does religiosity and spirituality influence employees output positively or negatively at workplaces? The extent to which different employees exhibit their spirituality or religious beliefs in many organisations is a major concern to many researchers since the ability or inability to understand these complexities will have their own associated consequences. The study therefore examines the impact of religiosity and spirituality on Ghanian organisations.

The practice of religiosity and spirituality has negatively affected Ghanaian level of thinking, values, ethics and attitudes. The attitudes Ghanaians put up in the various working places are greatly influenced by their religion and that has great impact on employee's performance and productivity in Ghana (King et al, 2018). It is a common practice that many employees in Ghana begin or commence their daily routine activities or work schedule with a well-organised religious activity such as morning devotion which all employees must participate. They do that with believe of casting away demons or any unfortunate thing likely to impede the progress and growth of such organization (Petchsawang and McLean, 2017).

\subsection{Profile of the Study Area}

According to the annual report of the Ministry of town and country planning 2013, Ahafo-Ano South District was carved or created out of the then Ahafo-Ano District in 1988 (L.I. 1401) in pursuance of governments decentralization programme. The Ahafo Ano South district has been divided into 10 Area Councils and further subdivided into 50 electoral areas. The District Assembly is composed of 50 elected and 21 appointed members, Members of Parliament and the District Chief Executive (DCE). The district is made up of two constituencies and therefore has two Members of Parliament, who are ex-officio members or members of the Assembly without voting rights. At its full sitting, the Ahafo-Ano South District Assembly is made up of 73 members.

\subsection{Area of Coverage}

The Ahafo Ano South district can be found or is located in the North-Western part of the Ashanti Region and shares common boundaries or borders with Tano South District (Brong Ahafo Region) to the North, Atwima Nwabiagya and Atwima Mponua districts to the South, Ahafo-Ano North District to the West and Offinso Municipal Assembly to the East. Mankranso is the district capital, and other important towns are Sabronum, Kunsu, Mpasaaso Nos. I \& II, Adugyama, Pokukrom and Abesewa. The district covers an area of 1,241 sq. km., representing approximately 5.8 percent of the region's total surface area.

\subsection{Population of the District}

The 2010 Population and Housing Census gave the total population of the district as 133,632, representing about 3.7 percent of the region's total population. With a growth rate of 3.1 percent and projection based on the 2000 Population and Housing Census Report, the estimated population of the district for 2010 was 181,341. Males form about 55.2 percent of the total estimated population and females, 44.8 percent. The rate at which the population is growing means that the population density will be increasing. In 1984, the population density was 65.9 per sq. km. It increased to 107.6 per sq. $\mathrm{km}$. in 2000 . In 2010 , the population density was estimated as 146.1 per sq. $\mathrm{km}$. About 47 percent of the district's current population is estimated to be in the age group 0-14 years, whilst those 15-59 years from about 40.5 percent. Those 60 years and above form about 12.5 percent of the total estimated population. 
The dependent population is quite high and currently the dependency ratio is 1:1.5. The high dependent population is one of the major causes of rural poverty and deprivation as many households are unable to meet their basic needs of food, health, education and clothing. Another implication of the youthful population is its potential to grow rapidly which invariably leads to increased demand for social facilities such as schools, clinics and playing grounds.

\subsection{The District Economy}

In terms of output, income and employment, agriculture is the most important economic activity in the district. The sector employs about 70.2 percent of the labour force and it is estimated that 75 percent of income of people in the district comes from agriculture.

Farming in the district is mostly subsistence and the farmers cultivate food and cash crops. The main food crops produced, to mention a few, are cassava, plantain, cocoyam, maize, yam, and vegetables. The cash crops are cocoa, citrus, and palm fruits. The district has a tremendous agricultural potential and is one of the major cocoa and food crop producing districts in the region.

The industrial sector constitutes the second important sector, employing 19.4 percent of the labour force in the district. The district has small scale cottage industries like palm oil extraction, akpeteshie distilling, soap making, cassava processing, and kente weaving. Communities noted for these activities include Nsutam, Barniekrom, and Onyinanufu. There are brick and tile factories at Biemso No. 2 and Mankranso. Timber industries are in and around Mankranso and Nsuta.

The services sector employs 13.6 percent of the labour force. This sector includes all public servants in the district. Other activities under this sector include banking, transport, and private health care and educational service delivery.

The commerce sector forms 6.8 percent of the total labour force. It comprises wholesale and retail trade with women dominating this sector. The district has 4 weekly markets. These are Kunsu, Adugyama, Pokukrom, and Sabronum markets. There are also small daily markets in other communities like Mankranso, Wioso, and Domeabra.

\subsection{Health}

Ahafo-Ano South District has one main hospital which is at the district capital, Mankranso. There are health centres at Mpasaaso, Sabronum, Pokukrom, and Wioso; and Community Health compounds at Essienkyem, Kunsu Dotiem, Mpasaaso Dotiem and Anitemfe. There are private health facilities at Asibey Nkwanta, Adugyama and Bonkwaso No.2. There are also mission clinics at Adugyama and Domeabra. There is only one medical doctor in the district and a few well qualified health personnel which make health service delivery difficult.

\subsection{Education}

The district has 95 nurseries/kindergartens, 96 primary schools, 58 Junior High Schools and one Senior High School. All these schools are public institutions. Private schools are few in the district. The provision of educational infrastructure such as school buildings, furniture, and sanitary facilities to improve the standard of education in the district continues to be the major priority of the Assembly.

\subsection{Religion}

The district has majority of its population being Christians or Muslims and can boost of forty three (43) different denominations and five (5) mosques.

\subsection{Research Design}

A mixed research method was used. A mixed method is an approach that combines both qualitative and quantitative research methods in the collection of data (Creswell and Clark, 2007). The research was conducted in an area where there are varied groups of people so the descriptive research design was considered appropriate. The study fits within the framework of descriptive survey research design because the researcher was to collect data and report the way things are without manipulating any variables. Saunders, Lewis and Thornhill (2012) maintain that the descriptive research design investigates into the conditions or relationships that exist, practices that prevail, beliefs or attitudes that are held. This design was considered appropriate for the study as it allowed the researcher to use questionnaire, observation and group interviews to obtain responses from participants and provide insight. The data was collected from primary and secondary sources. The primary source of data were obtained from the respondents using questionnaire. The secondary sources were retrieved from the existing literature. The questionnaire consisted of open and close ended questions. The respondents were supposed to choose an option from the close ended questions and supply answers to the open ended questions.

\subsection{Total Population}

This refers to the total number of employees in the town or district capital under study. The respondents were made 
up of various categories of people who work in different departments and agencies and with diverse educational, economic, social, political and religious backgrounds. The district capital has a working population of one thousand five hundred and seventy eight $(1,578)$. Out of this population, a simple random sampling technique was applied in selecting the sample size of two hundred and one (221) for the study. The following organizations were selected for the study. They are Education service, Health sector, National Health Insurance, National Disaster Management Organization (NADMO), and The District Police.

\subsection{Sample.}

Respondents were selected from the different sectors in the district capital. The Table 1 shows it.

Table 1. Sample Size from the Working Staff in the District

\begin{tabular}{|l|c|}
\hline Working staff in the District & No of Employee \\
\hline District Education Service & 92 \\
\hline Health Sector & 40 \\
\hline District Assembly workers & 30 \\
\hline National Health Insurance staff & 20 \\
\hline Ghana Police Service staff & 10 \\
\hline National Disaster Management Organisation (NADMO) Staff & 10 \\
\hline Ahafo-Ano Premier Rural Bank Limited & 12 \\
\hline National Commission on Civic Education (NCCE) Staff & 7 \\
\hline Total & $\mathbf{2 2 1}$ \\
\hline
\end{tabular}

Source: Authors' Own Construct, 2019

\subsection{Sampling Techniques}

The purposive and simple random sampling techniques were used to select the respondents from various government departments in the capital. These sampling techniques were chosen because the respondents could be reached easily and personally on face-to-face basis. Saunders et al (2012) stated that the techniques are suitable for all sample sizes. They are of the view that it gives accurate data and mostly needed when face-to-face contact is required and relatively easy to explain.

\section{Results}

\subsection{Practicing Religiosity at the Workplace}

Table 2 explains how workers in some organizations practice religiosity and spirituality at their workplaces. The respondents were supposed to give means of exhibiting religiosity and spirituality at the work place.

Table 2. Practicing Religiosity at the Workplace

\begin{tabular}{llllllll}
\hline $\begin{array}{l}\text { Religiosity } \\
\text { Anytime I arrive at my workplace, }\end{array}$ & 2 & 3 & 4 & 5 & 6 & 7 \\
\hline $\begin{array}{l}\text { I pray before I start work } \\
\text { I normally wear my religious cloths, }\end{array}$ & $11(5.0)$ & $16(7.2)$ & $4(1.8)$ & $21(9.5)$ & $43(19.5)$ & $57(25.8)$ & $69(31.2)$ \\
$\begin{array}{l}\text { Caps, shirts and others to work } \\
\text { I use religious objects like books, } \\
\text { calendars, rosary/tasbar, hand bands } \\
\text { and stickers at my workplace }\end{array}$ & $67(30.3)$ & $72(32.6)$ & $13(5.9)$ & $6(2.7)$ & $24(10.9)$ & $21(9.5)$ & $18(8.1)$ \\
$\begin{array}{l}\text { I belong to a religious group at my } \\
\text { workplace }\end{array}$ & $55(24.9)$ & $48(21.7)$ & $8(3.6)$ & $13(5.9)$ & $35(15.8)$ & $36(16.3)$ & $26(11.8)$ \\
$\begin{array}{l}\text { My religious group normally organizes } \\
\text { activities for its members to attend }\end{array}$ & $57(25.8)$ & $53(24.0)$ & $10(4.5)$ & $7(3.2)$ & $18(8.1)$ & $52(23.5)$ & $24(10.9)$ \\
$\begin{array}{l}\text { My organization allows formation of } \\
\text { religious groupings at workplace }\end{array}$ & $61(27.6)$ & $60(27.1)$ & $11(5.0)$ & $16(7.2)$ & $21(9.2)$ & $36(16.3)$ & $16(7.2)$ \\
$\begin{array}{l}\text { My religious group members normally } \\
\text { use similar objects to distinguish its } \\
\text { members from others }\end{array}$ & & $64(29.0)$ & $8(3.6)$ & $5(2.3)$ & $16(7.2)$ & $32(14.5)$ & $17(7.7)$ \\
\hline
\end{tabular}




\begin{tabular}{lllllllll}
\hline Religiosity & 1 & 2 & 3 & 4 & 5 & 6 & 7 \\
\hline $\begin{array}{l}\text { My organization sometimes organizes } \\
\text { religious activities like thanksgiving } \\
\text { service for all workers to take part }\end{array}$ & $47(21.3)$ & $64(29)$ & $15(6.8)$ & $18(8.1)$ & $21(9.5)$ & $37(16.7)$ & $19(8.6)$ \\
$\begin{array}{l}\text { Some of the workers are sometimes } \\
\text { asked by the organization to perform } \\
\text { religious duties like leading worship }\end{array}$ & $25(11.3)$ & $42(19)$ & $16(7.2)$ & $14(6.3)$ & $30(13.6)$ & $59(26.7)$ & $35(15.8)$ \\
*I sometimes stop work to attend to \\
$\begin{array}{l}\text { religious activities like prayers } \\
\text { *My religious beliefs enjoins me to }\end{array}$ & $65(29.4)$ & $66(29.9)$ & $13(5.9)$ & $8(3.6)$ & $19(8.6)$ & $29(13.1)$ & $20(9.0)$ \\
work with my whole being & $8(3.6)$ & $22(10.0)$ & $5(2.3)$ & $9(4.1)$ & $26(11.8)$ & $87(39.4)$ & $63(28.5)$ \\
$* \begin{array}{l}* \text { I consider my work as part of my } \\
\text { calling by my creator }\end{array}$ & $8(3.6)$ & $15(6.8)$ & $7(3.2)$ & $(5.0)$ & $20(9.0)$ & $86(38.9)$ & $73(33.0)$ \\
*My religious beliefs do not affect & $10(4.5)$ & $24(10.9)$ & $6(2.7)$ & $9(4.1)$ & $20(9.0)$ & $84(38.0)$ & $67(30.3)$ \\
\hline
\end{tabular}

\begin{tabular}{lll}
\hline Source: Field survey, $2019 \quad * 1(0.5 \%)$ missing from the system \\
$7=$ Agree & $6=$ Strongly Agree & $5=$ Slightly Agree \\
$4=$ Disagreed & $3=$ Strongly Disagreed & $2=$ Slightly Disagree
\end{tabular}

$1=$ Neither Agree nor Disagree.

The responses received from respondents on the question of praying before the start of work upon arrival at the workplace, 57(25.8\%) agreed and 69(31.2\%) strongly agreed. This same issue had 11(5.0\%) and 16(7.2\%) strongly disagreeing and disagreeing respectively. $43(19.5 \%)$ slightly agreed while $21(9.5 \%)$ neither agree nor disagree.

Another practice of religiosity in relation to the use of religious dresses like clothes, shirts, T-shirts, caps among others, $9.5 \%$ agree that they use them and $8.1 \%$ strongly agreed. $10.9 \%$ slightly agreed whereas $32.6 \%$ disagree, $30.3 \%$ strongly disagree, $5.9 \%$ slightly disagree and $2.7 \%$ neither agreed nor disagree. Again, on the display of religious objects such as calendars, books, pennants, stickers, flags, posters, and hand bands, those who agreed were $16.3 \%$. Workers who strongly agreed were $11.8 \%$ and $15.8 \%$ slightly agree that they use them. On the other hand, $24.9 \%$ strongly disagreed, $21.7 \%$ disagree and 3.6\% slightly disagree. $5.9 \%$ neither agreed nor disagreed. The suggestion that indicated to them that each belonged to a religious group at their places of work had these responses: $14.5 \%$ agree, $7.7 \%$ strongly agree, and $7.2 \%$ slightly agree. However, $29.0 \%$ disagreed, $35.7 \%$ strongly disagree and $2.3 \%$ stated that they neither agreed nor disagree. These responses indicate that there is liberty for each employee to belong to any religious group of his or her choice.

The question on the organization sometimes organizing religious activities like thanksgiving service for all its employees to participate brought these answers out. $8.1 \%$ neither agree nor disagree, $16.7 \%$ agree, $21.3 \%$ disagree, $8.6 \%$ strongly agree, $21.3 \%$ strongly disagree, $9.5 \%$ slightly agree and $6.8 \%$ slightly disagreed. These diverse answers show that while some organizations normally do organize such activities others do not do that and some are not in the known whether their organizations do it or do not undertake such activities.

In the course of the performance of religious activities, the organization sometimes requested some staff to execute religious duties like leading of worship. The responses received included the following. $26.7 \%$ said they agree, $15.8 \%$ strongly agree and $13.6 \%$ slightly agree but $11.3 \%$ strongly disagree, $19.0 \%$ disagree and $7.2 \%$ slightly disagree with $6.3 \%$ saying they neither agreed nor disagreed. This also goes to support the first question's answers which are of diverse nature. In the opinion of the researcher, leading worship is a way of exposing their members to be well vexed in public speeches and socialization.

The question of sometimes stopping work to attend to religious activities like prayers showed these feedbacks. $13.1 \%$ agreed, $9.0 \%$ strongly agreed, $8.6 \%$ slightly agreed. Others however disagreed on varied degrees as $29.9 \%$ disagreed, $29.4 \%$ strongly disagreed, $5.9 \%$ slightly disagreed and $3.6 \%$ neither agreed nor disagreed. From these, one can see that while some do stop work for prayers, others do not do it and some still are neutral.

The assertion that religious beliefs enjoin workers to work with their whole being had these major reactions from respondents. $39.4 \%$ agreed, $11.8 \%$ slightly agreed, $28.5 \%$ strongly agreed but $10.0 \%$ disagreed, $3.6 \%$ strongly disagreed, $2.3 \%$ slightly disagreed while $4.1 \%$ neither agreed nor disagreed. Also, those who considered their works as part of their divine calling constituted these percentages. $38.9 \%$ agreed, $9.0 \%$ slightly agreed, $33.0 \%$ strongly agreed. However, $6.8 \%$ disagreed, $3.6 \%$ strongly disagreed and $3.2 \%$ slightly disagreed while $5.0 \%$ 
neither agreed nor disagreed. Then, the suggestion that religious beliefs do not affect workers attitude to work saw these mixed answers. $38.0 \%$ agreed, $30.3 \%$ strongly agreed and $9.0 \%$ slightly agreed. $10.9 \%$ disagreed, $4.5 \%$ strongly disagreed, $2.7 \%$ slightly disagreed and $4.1 \%$ neither agreed nor disagreed.

\subsection{Discussions}

The responses show that there is the enthusiasm of workers to openly declare their commitment to their religion and spirituality freely without any hindrance. To the researcher, these actions will encourage members to socialize and develop strong interpersonal relationships among them thereby reducing tensions and suspicions. All these issues deal with internal feelings of employees, as a result of one's level of religiosity and spirituality and then affect their attitudes to work which also determine performance.

Then, what links humankind to God is religion and at the same time provides for an individual's good and clear conscience (Pandey and Singh, 2019). It is again stated that, practical activities individuals exhibit at workplaces to demonstrate their religiosity include recitation of prayers every day (Oxhandler, 2019). Thus, it can further be stated that it is a common sight to find workers or managers praying in their offices. This is also true to see a whole group of workers beginning their daily activities with an organized prayer service. This means that the majority of employees communicate with the Divine every day as a way of practicing their religiosity before they commenced their official functions at their workplaces. This confirms what Hill et al (2019) said which indicated that man is incurably religious and every activity man undertakes has religiosity and spirituality attached.

According to Alas and Mousa (2016), the display of such paraphenarial is to convey to people a message about their loyalty and want to persuade co-workers to adopt their symbolic messages. Lizano et al. (2019) continued to show that, some employees can put on religious regalia or artifacts like the crucifix, rosary, and 'tasbar' to their places of work. Lizano et al. (2019) wrote that religious headscarves are normally put on by women especially the types designed with religious logos and 'hijab' (headscarf) by Muslim women and the cap by the men. Most workers hang printed religious posters and calendars in their offices to demonstrate their spirituality. It is also a common sight as stated by Oxhandler (2019) that on the tables or office desks can be found religious scriptures and tracts which are read by owners or possessors. To buttress the above assertions that workers mostly practice religiosity by exhibiting religious paraphilia, a female worker at Mankranso during one-on-one interview said

"There was not even a single day that I will go to work without putting on any of my church paraphilia ever since I started this work and also joined Pentecost church. Over the years, I have tried, as an eldering member of the church, to encourage women to cultivate this habit. With regards to this, we have ordered each male church member to involve his wife in putting on the church's paraphilia to their workplaces to advertise their church to others. This will eventually enhance and increase the church population" (Fieldwork, 2019).

On the whole, majority of the respondents were in support of the question. This shows that there is a wind of freedom blowing at most workplaces but others are not allowed to enjoy this constitutional rights of freedom of association as enshrined in the 1992 Republican Constitution of Ghana chapter five clause 21(1)(b, c, d, and e).

On the issue of religious group members normally using similar objects to distinguish its members from others, celebrating festivities and enhancing peace indicate that at least there is some sort of using similar objects as a form of special identification at some workplaces to promote peace in their working places. This corroborates Alas and Mousa (2016) assertion that religious observances and obligations like prayers, Sabbaths, festivals and holy days are to be given the needed attention to cater for minority interests (Ayoun et al, 2015). For example, during festive occasions like the Muslim end of Ramadan period -'Idr ul Fitr'- and festival of sacrifice - 'Idr $u l$ Adha' celebrations and also during Christmas and Easter seasons being celebrated by Christians. Again, the employees are given the chance to take an active part and even close down for workers to feel that they are part of the system (King, 2018). It was stated by Chenoweth and McAuliffe, (2017) that religiousness encompasses all situations where an individual is considered as being self-righteous and then attend religious services, programmes and activities regularly. The researcher agrees with Rothmann et al (2019) who brought out their statement to the effect that religion has been able to provide actual peace and happiness to individual people and also to do good stems from the guiding principles derived from the Divine and that, individuals perform good acts through appeal to their will and not through the use of coercive force. According to them, religion is the source that gives guidelines to progress for man both from the material and the spiritual perspectives. They are also of the view that no individual can discuss the issues of morality and virtue without reference to religion since morality and virtue emanates from one's good and clear conscience.

Generally, on religiosity and spirituality, it is therefore prudent to agree with Hill et al (2019) that religion cannot be detached from the very fabric of the African and that religion and the African are inseparable and nothing can be done to remove or take religion from the life of the African (Hill et al 2019).

It is important to draw attention to the fact that within organisations are individual employees who congregate at one place to work for owners of businesses. So these practices will be looked at from the individual, the group and organisational levels. From Table 3, the responses gathered on how spirituality is practiced at the workplace 
are presented and analysed.

Table 3. Practicing Spirituality at the workplace

\begin{tabular}{|c|c|c|c|c|c|c|c|}
\hline Spirituality & 2 & 3 & 4 & 6 & 7 & & \\
\hline $\begin{array}{l}\text { *When I am faced with an important } \\
\text { decision, my spirituality is always the } \\
\text { overriding consideration }\end{array}$ & $12(4.5)$ & $13(5.9)$ & $14(6.3)$ & $24(10.9)$ & $47(21.3)$ & $75(33.9)$ & $36(16.3)$ \\
\hline $\begin{array}{l}\text { * Spirituality is the master motive of my } \\
\text { life, directing every other aspect of my } \\
\text { life not part of my life }\end{array}$ & $13(5.9)$ & $21(9.5)$ & $12(5.4)$ & $14(6.3)$ & $45(20.4)$ & $76(34.4)$ & $40(17.2)$ \\
\hline $\begin{array}{l}\text { *When I think of things that help me to } \\
\text { grow and mature as a person, my } \\
\text { spirituality is absolutely the most } \\
\text { important factor in my personal growth }\end{array}$ & $6(2.7)$ & $15(6.8)$ & $8(2.7)$ & $16(7.2)$ & $37(16.7)$ & $84(38.0)$ & $55(24.9)$ \\
\hline $\begin{array}{l}\text { *My spiritual beliefs affect no aspect } \\
\text { Of my life }\end{array}$ & $40(18.1)$ & $45(20.4)$ & $13(5.9)$ & $13(5.9)$ & $20(9.0)$ & $47(21.3)$ & $41(18.6)$ \\
\hline
\end{tabular}

Source: Field survey, $2019 \quad * 2(0.9 \%)$ missing from the system

Table 3 illustrates that indeed practicing spirituality at the workplaces has made a lot of contributions to the productivity in the study area. When workers were asked to give answers to the issue that when they are faced with any important decision, their spirituality becomes always the overriding consideration, a significant number of the respondents representing $36 \%$ of the workers strongly agreed that practicing spirituality had improved their living conditions as well as productivity. The reason given by the respondents was that before they started their work they were practicing spirituality at home. When they faced with an important decision, their spirituality is always the overriding consideration. It is on the basis of this that the researcher opines that whatever employees do at their workplaces are based on their levels of spiritual growth and maturity. The results confirmed that of Aboobaker and Edward researched in 2019. Their research supported the view that any attitude exhibited by employees which resembles that of a servant's behaviour towards an individual's occupation and management is a sign of spirituality. He again pointed out that as one demonstrates respect, kindness, love, honesty and a high sense of integrity, it shows spirituality at work (Aboobaker and Edward, 2019). In this regard, a 41 year old worker at Makranso, during focus group discussions, testified that

"Spirituality brings about creativity, communication, respect, vision, partnership, energy and flexibility. He further explained that creativity symbolizes the application of colour, laughter and enjoying one's total freedom which will promote greater productivity. Communication is the means through which workers team-up and operates properly or which enables workers to work as a team. In addition, he lamented that there is respect for oneself and also of other workers etc". (Field survey, 2019).

Whitworth et al. (2019) reinforced the above quotation that workers creativity includes enjoying what they are doing, they tend to work much harder or put up their best from within themselves and communication enhances teamwork or working together and this makes them feel to be within the group willingly. Respect involves showing respect for the environment one works within, respecting colleague's personal privacy, their physical space and properties, their diverse opinions, religious affiliations, gender, philosophies, an individual's ethnic origin, physical ability and personality. They indicated that demonstrating vision implies the capacity to perceive beyond the ordinary or the obvious. Thus, when one sees what others cannot see with the mind in the near future and prepares for it. Then, partnership involves the duties and trusts assigned to people to execute in relation to their commitments towards the betterment of the group and the organization's stakeholders.

Furthermore, on the question that spirituality is the master motive of their lives, directing every aspect of their lives not part of them, $34.4 \%$ strongly agreed and $6.3 \%$ neither agree nor disagree indicating diversity of respondents' spirituality in the district. Majority of the respondents strongly agreed that spirituality is the master motive of their lives, directing every aspect of their lives not part of them buttress the assertion by Mahmood et al, (2018) that different individuals possess diverse standpoints and beliefs and this diversity is employed positively to expand the experiences of the members of the group. Energy they say is the stored up power for work and argued further that anytime workers feel creative and experience the freedom to vent their grievances and thoughts, and also being respected from the highest echelon or the top management and supervisors and from their own colleagues or co-workers, positive energy forces are released or discharged from within individuals to enhance their personalities. They emphasised that employees need to be flexible and flexibility encompasses the capacity to adapt to dynamic situations or keep up with the wind of change which blows across the work environment. They further explained that flexibility means agreeing to have an individual's personal beliefs and habits to change when 
required. Thus, one has to find his real position on this universe or earth and move within its energy to attain greater feats or heights. They are of the view that there is fun whenever individuals who experience their lives positively put in much effort, earn much income or money, develop greater confidence in themselves, relate to many good friends and are seen as healthier as compared to those who do not have fun in their lives. Again, when one thinks of things that help him/her to grow and mature as a person, their spirituality is absolutely the most important factor, $38.0 \%$ agreed, $24.9 \%$ strongly agreed, and $7.2 \%$ neither agree nor disagree. Once again varied answers were obtained. This indicates that, majority of the respondents favour positively all the spirituality questions with some dissenting. It is on the basis of this that the researcher opines that whatever employees do at their workplaces are based on their levels of spiritual growth and maturity.

\subsection{The Influence of Religiosity and Spirituality on Performance}

It has been pointed by Oxhandler, (2019) that workers of today find it extremely daunting to detach their work from their spiritual daily activities. Employees continue to seek meaning in the work they perform in order to bring their lives in equilibrium. This stems from the fact that currently, no employee wants to work under an autocratic leader or manager and in an environment which degrades humanity (Oxhandler, 2019). Effective manifestation of religiosity and spirituality at the individual, the group and the company levels yields great benefits according to Pandey and Singh (2019). Some of these benefits accrued from the practice of spirituality at the workplace include being creative, improved production processes, better service to customers, being honest and trustworthy, having personal fulfillments, and being committed to the work one does. These ultimately culminate in higher performance levels in the organisation. In addition to these, Farmer et al, (2019) wrote that workers who experience the feeling that they are directly connected to their work enjoy total peace of mind, internal or inner strength, serenity, sanity, calmness, and show patience and further demonstrate right attitude to work. The end result or product in better performance by employees is to help produce quality products and services (Farmer et al, 2019). The researcher agrees with East and opines that due to these benefits, it will be prudent for the Human Resource Manager to watch out to the best way of achieving consistent workplace harmony using religiosity and spirituality.

According to Whitworth et al, (2019), workplaces where spirituality has been clearly seen to be in operation, such organisations have performed better in terms of profitability. He again wrote that "the more spirited companies outperform the others by 400 to 500 percent, in terms of net earnings, return-on-investment and shareholder value" (Cullen, 2016). Added to this assertion is the statement that companies that have promoted religiosity and spirituality witnessed greater success and profits (Ahmed et al, 2016; Omoegun et al, 2018). Workplace religiosity and spirituality can result into intuition which also results in creativity. Omoegun et al, 2018 again, postulates that any time workers are given the opportunity to exhibit their spiritual life at the workplace, they demonstrate a high sense of creativity which in turn produce excitement and contentment in them. Whitworth et al, (2019) support Aboobaker and Edward (2019) by adding that bringing their spiritual sides to work will thereby lead to successes in monetary terms for the company. This assertion is totally true as the aim of every company is to make more profits. In the same way, the performance of the organisation is duly influenced by religiosity and spirituality which is positively found there (González-González, 2018).

Moreover, workers' creativity, contentment, working in teams, and total dedication to the course of the organisation were enhanced in organisations which enabled religiosity and spirituality to flourish at its workplaces (Mahmood et al, 2018; Pawar, 2016). In the case of individuals experiencing fulfillment, Pawar, (2016) observed that enhancing or promoting religiosity and spirituality will bring about workers going through total completeness or wellbeing anytime they report for work. The end product of this is the greater levels of individual fulfillment and the higher morale which in turn results in high performance in the organisation derived from successes in monetary terms. Burack stated in relation to commitment that when there is a rise in commitment which comes about as a result of spirituality, it paves the way for "Trustful Climate" at the place of work (Blount, 2018). This commitment encompasses that of the workers to the company and also the company's commitment to quality and that of the buyer (Abu Bakar et al, 2018). Workers' attitudes in companies where religiosity and spirituality operates freely is positive, they serve as supporters and exhibit high levels of commitment as compared to the organisation where there is negative activities or where spirituality is stifled (King, 2018; Lizano et al, 2019). This means that workers' being religious and spiritual affect their performance and the output of the organisation.

\subsection{Conclusion}

The following conclusions are therefore drawn from the findings. First, it could therefore be concluded that most Ghanaian workers practice religiosity and spirituality at workplaces, they practice that through wearing religious paraphilia and it could also be concluded from the findings that religiosity and spirituality are positively related and goes hand in hand in life, as well as most organizations allow formation or religious groupings at the workplace. other are most employees consider their works as a divine calling and hence put in much efforts to bring out the best of their abilities, religiosity and spirituality enhanced output through commitment and hard work, benefits accrued from the practice of spirituality at the workplace include creativity, improved productivity, better service 
to customers, honesty and trustworthy as well as having personal fulfillments and employees result to spirituality to find solutions to life problems and when taking serious decisions.

\subsection{Recommendations}

In the light of the discussions, findings and the conclusions, the following recommendations are hereby coined;

1. Management must designate special areas for religious activities like prayers and meditations for the employees to dialogue with their maker.

2. Again, management must also be specific and positive by stating guidelines clearly and root them as much as possible in business terms such as the type of garments they are permitted to wear to work.

3. Furthermore, management must as a matter of urgency, endeavour to provide holiday swapping or floating policies to make it easier for diverse religious groupings to take time off to celebrate the various holidays that are useful to them.

These recommendations on the practices stated that human behaviour is regulated by morals which radiates from extremely high religiosity and spirituality. It is prudent to further say that those who reject religiosity and spirituality outright and thereby are deprived of good spiritual values, find it extremely daunting to sustain conduct in relation to the principles of morals. These morals emanate from the practice of religiosity and spirituality.

\section{Reference}

Aboobaker, N., \& Edward, M. (2019). Workplace spirituality, employee wellbeing and intention to stay: A multigroup analysis of teachers' career choice. International Journal of Educational Management, 33(1), 28-44.

Abu Bakar, R., Cooke, F. L., \& Muenjohn, N. (2018). Religiosity as a source of influence on work engagement: a study of the Malaysian Finance industry. The International Journal of Human Resource Management, 29(18), 2632-2658.

Ahmed, A., Arshad, M. A., Mahmood, A., \& Akhtar, S. (2016). Spiritual intelligence (SQ): a holistic framework for human resource development. Administratie si Management Public, (26), 60.

Alas, R., \& Mousa, M. (2016). Organizational culture and workplace spirituality. International journal of emerging research in management and technology, 5(3), 285-314.

Ayoun, B., Rowe, L., \& Yassine, F. (2015). Is workplace spirituality associated with business ethics? International journal of Contemporary hospitality management, 27(5), 938-957.

Blount, A. (2018). Intentional Practices of Christian Schools for Spiritual Formation of Third-and Fourth-Grade Students: A Multiple Case Study.

Chenoweth, L., \& McAuliffe, D. (2017). The Road to Social Work and Human Service Practice with Student Resource Access 12 Months. Cengage AU.

Cullen, J., G. (2016). Nursing management, religion and spirituality: A bibliometric review, a research agenda and implications for practice. Journal of Nursing Management, 24(3), 291-299.

Farmer, M., Allen, S., Duncan, K., \& Alagaraja, M. (2019). Workplace spirituality in the public sector: a study of US water and wastewater agencies. International Journal of Organizational Analysis.

Fox, C., Webster, B. D., \& Casper, W. C. (2018). Spirituality, psychological capital and employee performance: An empirical examination. Journal of Managerial Issues, 30(2), 194-153.

González-González, M. (2018). Reconciling spirituality and workplace: Towards a balanced proposal for occupational health. Journal of religion and health, 57(1), 349-359.

Gordon, A. (2018). Portraits of the Japanese workplace: labor movements, workers, and managers. Routledge.

Hill, H., Killaspy, H., Ramachandran, P., Ng, R. M. K., Bulman, N., \& Harvey, C. (2019). A structured review of psychiatric rehabilitation for individuals living with severe mental illness within three regions of the AsiaPacific: Implications for practice and policy. Asia-Pacific Psychiatry, e12349.

King, S. M. (2018). Leading Large without Losing Soul: Equipping Senior Pastors of Large Congregations to Discover, Nurture, and Lead from the True Self (Doctoral dissertation, Mercer University).

Lizano, E. L., Godoy, A. J., \& Allen, N. (2019). Spirituality and worker well-being: examining the relationship between spirituality, job burnout, and work engagement. Journal of Religion \& Spirituality in Social Work: Social Thought, 1-20.

Mahmood, A., Arshad, M. A., Ahmed, A., Akhtar, S., \& Khan, S. (2018). Spiritual intelligence research within human resource development: a thematic review. Management Research Review, 41(8), 987-1006.

McCormick, D.W. (1994). Spirituality and Management. Journal of Managerial Psychology, 9(6): 5-8.

Milliman, J., Gatling, A., \& Kim, J. S. (2018). The effect of workplace spirituality on hospitality employee engagement, intention to stay, and service delivery. Journal of Hospitality and Tourism Management, 35, 5665.

Omoegun, O. M., Nwadinigwe, I. P., \& Ahimie, B. (2018). Factors that Hinder Work-Place Counselling Services in Nigeria. Covenant International Journal of Psychology, 3(22018).

Oxhandler, H. K. (2019). Revalidating the religious/spiritually integrated practice assessment scale with five 
helping professions. Research on Social Work Practice, 29(2), 223-233.

Pandey, J., \& Singh, M. (2019). Positive Religious Coping as a Mechanism for Enhancing Job Satisfaction and Reducing Work-family Conflict: A Moderated Mediation Analysis. Journal of Management, Spirituality \& Religion, 1-25.

Pawar, B. S. (2016). Workplace spirituality and employee well-being: An empirical examination. Employee Relations, 38(6), 975-994.

Petchsawang, P., \& McLean, G. N. (2017). Workplace spirituality, mindfulness meditation, and work engagement. Journal of Management, Spirituality \& Religion, 14(3), 216-244.

Rothmann, S., Weiss, L. A., \& Redelinghuys, J. J. (2019). Cultural, National, and Individual Diversity and their Relationship to the Experience of Meaningful Work. The Oxford Handbook of Meaningful Work, 429.

Tylor, E.B. (1976 [1929]). Primitive Culture. London; John Murray.

Vasconcelos, A. F. (2018). Workplace spirituality: empirical evidence revisited. Management Research Review, 41(7), 789-821.

Whitworth, J. D., Stewart, C., \& Woodard, R. J. (2019). Managing the results trap: Resources drawn from the integration of spirituality, religion, and practice. Journal of Religion \& Spirituality in Social Work: Social Thought, 1-17.

Charles Aidoo Tawiah (MBA) is a tutor of Religious and Moral Education, Berekum College of Education, University of Cape Coast, Ghana. He is also a trainer on the new curriculum of Religious and Moral Education for Basic Schools by giving the implementers proper training for effective implementation.

Augustina Kyeraa (MBA) is the general secretary of Berekum College of Education, University of Cape Coast, Ghana. Her field of mastery is management and religious and moral education. She has been in this profession for over eight years. This is her first time trying to publish in management journal.

Patrick Twumasi Frimpong (MBA) is a worker of Sunyani Technical University, Sunyani. He is the head of Provident and also in charge of credit union of Sunyani Technical University.

Hans Kwaku Duah (Mphil, PhD student) is an Environmental/Social Studies tutor at the Berekum College of Education, University of Cape Coast. He did his first degree in Geography and urban planning. He is currently pursuing a PhD in Geography and Rural Development, focusing more on the Herbal Medicine. This is his first time of publishing in management journal though, he has published in other journals.

Address: Berekum University College of Education. 